\title{
PEMILIHAN RANCANGAN RODA GIGI BERDASARKAN KARAKTERISTIK MATERIAL DENGAN METODE ELECTRE
}

\author{
Taufiq Rochman *1) \\ 1), Program Studi Teknik Industri, Fakultas Teknik \\ Universitas Sebelas Maret, Jl. Ir. Sutami, 36 A, Surakarta
}

\begin{abstract}
Gears is one of machine elements, cylindrical wheels used for transmitting motion and power from one rotary shaft to anothers. The design of the gear is part of the engineering design activities to produce products that are not only superior in terms of technology but produce the design in accordance with the designer. The design of gear involves extensive procedure, complex calculations and many design decision. It is necessary for the design of the gear based on characteristics of material that matches the designer whishes. The characteristics of material on which to base the design include the size of the geometry, the contact stress, bending stress, precision standard and transmission conditions. Selection of gear design to consider the characteristic materials through multi criteria decision making approach. The ELECTRE method is one of MCDM method used to help decision makers choose the best alternative with outranking approach. The results of the analysis with the model ELECTRE is best alternative consists of alternative 3 that has some design criteria includes: contact stress, , bending stress, precision based on the ISO 1328 standard, transmission conditions and the size of the geometry. According to these calcultion, the absolute dominance grading was determined as alternative $3>$ alternative $1>$ alternative $4>$ alternative 2 .
\end{abstract}

Keywords: design of gear, material characteristic, MCDM, outranking, ELECTRE.

\section{PENDAHULUAN}

Roda gigi adalah roda silindris bergigi yang digunakan untuk mentransmisikan gerak dan daya dari sebuah poros berputar ke poros berputar yang lain. Kualitas roda gigi adalah ketelitihan yang bersifat spesifik untuk sebuah roda gigi yang meliputi keragaman indeksi, kesejajaran gigi, profil gigi, jari-jari akar, dan keragaman gabungan total. Dalam perancangan roda gigi dipertimbangkan bahan-bahan pembentuk dengan berbagai keragaman dan sifatnya seperti ketetapan prancangan mekanis, ketahanan dan kekuatan terhadap cacat muka, selain itu dipertimbangkan pula kemampuan produksi roda gigi, persiapan bakal roda gigi, pembentukan gigi-gigi roda gigi, perakitan roda gigi ke mesin, berat, tampilan, ketahanan terhadap korosi, suara dan biaya. (Mott, R.L. 2004). Karakteristik diatas menjadi bahan pertimbangan dalam memilih jenis rancangan roda gigi. Pemilihan rancangan dengan pertimbangan karakteristik material seperti besarnya tegangan lengkung, tegangan kontak, standar kepresisian, bentuk geometri dan kehalusan dalam pentransmisian menjadi faktor yang perlu dipertimbangkan untuk menghasilkan pilihan rancangan yang tidak hanya sesuai dengan standar kualitas tetapi juga sesuai dengan keinginan decision maker dalam mendisain produk. Studi ini bertujuan memilih rancangan roda gigi yang mendasarkan pada atribut-atribut kualitas material sesuai dengan ketetapan disain engeneering berdasarkan pendekatan Multi Criteria Decision Making.

Multi Criteria Decision Making (MCDM) adalah sub bagian dan cabang operational riset yang sedang tumbuh yang mendasarkan pada pendekatan matematika untuk mendukung evaluasi subyektif dari jumlah alternatif keputusan berdasarkan sejumlah performansi kriteria yang dilakukan decision maker baik tunggal atau kelompok (Karim \& Karmaker, 2016). MCDM berkaitan dengan screening, penetapan prioritas, perangkingan atau seleksi alternatif berdasar kriteria yang independent, tidak seimbang (incommensurate) dan konfliktual. Ada beberapa

\footnotetext{
*Correspondance : tofiqrochman@yahoo.com
} 
metode yang berkaitan MCDM diantarnya AHP, ANP, TOPSIS, ELECTRE, PROMETHEE, VIKOR, MAUT dan lain-lain. Uysal \& Vayuz (2014) menggunakan metode ELECTRE dalam pemilihan pusat lokasi logistik di Turki. Naghiu, et.al. 2015 menggunakan methode ELECTRE berkaitan dengan pemilihan panel solar radiation concentration for Photovoltaic di Rumania. Lozano, et.al. 2016 membandingkan metode TOPSIS dan ELECTRE TRI dalam menentukan letak yang optimal untuk penempatan photovoltaic solar farms di Spanyol. Korta J dan, Mundo D, 2017, melakukan optimasi multi objektif terhadap geometri roda gigi dengan metode Response Surface, Sedangkan Karim \& Karmaker (2016) menggunakan metode AHP \& TOPSIS dalam proses pemilihan mesin.

Pada kasus ini menggunakan metode ELECTRE untuk melakukan pemilihan rancangan roda gigi dengan cara melakukan perangkingan beberapa alternatif yang ditetapkan. Kelebihan metode ini adalah memiliki kemampuan untuk mengolah kriteria kuantitatif dan kualitatif diskrit secara alami dan memberikan pengurutan sampel secara penuh, mengakomodasi ketidakakuratan dan ketidaktentuan dalam proses pengambilan keputusan menggunakan nilai concordance, discordance dan threshold. Model ini digunakan untuk membandingkan 4 pilihan berdasarkan beberapa kriteria yang berpengaruh dalam perancangan roda gigi meliputi : aspek material berkaitan dengan tegangan kontak dan tegangan lengkung, standar kepresisian, ukuran geometri, dan kehalusan kondisi petransmisian.

\section{METODE ELECTRE}

ELECTRE adalah kepanjangan dari Elimination Et Choix Traduisant La Realite (Elimination and Choice Expressing the Reality) diperkenalkan oleh Bernard Roy pada tahun 1965. Metode ELECTRE adalah metode keputusan multikriteria berdasarkan pada konsep outranking dengan menggunakan perbandingan berpasangan dari beberapa alternatif berdasarkan dari kriteria-kriteria yang dipertimbangkan. Suatu alternatif dikatakan mendominasi alternatif lainnya jika satu atau lebih kriterianya melebihi kriteria dari alternatif lainnya.

Langkah-langkah dalam metode ELECTRE dilakukan untuk menyelesaiakan persoalan pengambilan keputusan dengan kriteria jamak dilakukan dengan tahapan sebagai berikut :

Step 1. Formation of Decision matrix (D)

Decision matrix $D$ mengacu terhadap $m$ alternatif yang akan dievaluasi berdasarkan $n$ kriteria yang didefinisikan sebagai berikut:

$D=\left[\begin{array}{cccc}X_{11} & X_{12} & \cdots & X_{1 n} \\ X_{21} & X_{22} & \cdots & X_{2 n} \\ \vdots & \vdots & & \vdots \\ X_{m 1} & X_{m 2} & \cdots & X_{m n}\end{array}\right]$

Step 2. Formation of Standard Decision Matrix (R)

Prosedur ini mengubah nilai atribut menjadi nilai yang comparable yang diperoleh dengan mengubah matrik $D$ menjadi matrik yang ternormalisasi. $R$ matrik hasil normalisasi menggambarkan $m$ = alternatif dengan $n=$ kriteria dan $r_{i j}$ adalah normalisasi pengukuran alternatif ke- $i$ dan kriteria ke-j.

$$
\begin{aligned}
r_{i j} & =\frac{x_{i j}}{\sqrt{\sum_{i=1}^{m} x_{i j}^{2}}} \text { untuk } i=1,2,3, \ldots, \text { m dan } j=1,2,3, \ldots, n . \\
R & =\left[\begin{array}{cccc}
r_{11} & r_{12} & \ldots & r_{1 n} \\
r_{21} & r_{22} & \ldots & r_{2 n} \\
\vdots & & & \\
r_{m 1} & r_{m 2} & \ldots & r_{m n}
\end{array}\right]
\end{aligned}
$$


Matrik hasil normalisasi $(R)$ dikalikan dengan bobot yang telah ditetapkan $\left(w_{j}\right)$ sehingga diperoleh matrik terbobot (weighted normalized matrix), formulasi pembobotan dengan perssamaan $V=$ $R W$ menghasilkan matrik terbobot.

$V=\left[\begin{array}{cccc}w_{1} r_{11} & w_{2} r_{12} & \cdots & w_{n} r_{1 n} \\ w_{1} r_{21} & w_{2} r_{22} & \cdots & w_{n} r_{2 n} \\ \vdots & \vdots & & \vdots \\ w_{1} r_{m 1} & w_{2} r_{m 2} & \cdots & w_{n} r_{m n}\end{array}\right]$

Step 4. Determination of Concordance $\left(C_{k l}\right)$ dan Discordance $\left(D_{k l}\right)$

Penentuan nilai concordance dan discordance berdasarkan perbandingan pasangan alternatif $k$ dan $l(k, l=1,2,3, \ldots m$ dan $k \neq l)$ dan kriteria $J$. Sebuah kriteria dalam suatu alternatif termasuk concordance jika : $C_{k l}=\left\{j, v_{k j} \geq v_{l j}\right.$, untuk $j=1,2,3, \ldots, n$. Komplementer dari himpunan bagian concordance adalah himpunan discordance, yaitu : $D_{k l}=\left\{j, v_{k j}<v_{l j}\right\}$, untuk $j=1,2,3, \ldots n$.

Step 5. Formation of Concordance $(C)$ and Discordance Matrices (D)

Menghitung matrik concordance berdasarkan nilai himpunan concordance dengan menggunakan formulasi berikut ini:

$$
c_{k l}=\sum_{j \in C_{k l}} w_{j}
$$

Menghitung matriks discordance dengan formulasi:

$$
d_{k l}=\frac{\max \left\{\left|v_{k j}-v_{l j}\right|\right\}_{j \in D_{k l}}}{\max \left\{\left|v_{k j}-v_{l j}\right|\right\}_{\forall j}}
$$

Step 6. Formation of Concordance Supremacy $(F)$ and Discordance Supremacy $(G)$ matrices.

Matriks F, matriks dominan concordance diperoleh dengan membandingkan nilai elemen matrik concordance terhadap nilai threshold $C_{k l} \geq \underline{c}$. besaran nilai threshold diperoleh dengan formulasi $(\underline{c})$ :

$\underline{c}=\frac{1}{m(m-1)} \sum_{k=1}^{m} \sum_{l=1}^{m} c_{k l}$

Sehingga elemen matriks $F$ ditentukan sebagai berikut:

$$
f_{k l}=\left\{\begin{array}{l}
1, j i k a c_{k l} \geq \underline{c} \\
0, j i k a c_{k l}<\underline{c}
\end{array}\right.
$$

Matrik $G$ sebagai matriks dominan discordance dapat diperoleh dengan membandingkan elemen matrik discordance dengan nilai threshold $\underline{d}$ :

$\underline{d}=\frac{1}{m(m-1)} \sum_{k=1}^{m} \sum_{l=1}^{m} d_{k l}$

Penentuan elemen matriks $G$ diperoleh dengan persyaratan perbandingan sebagai berikut:

$$
g_{k l}=\left\{\begin{array}{l}
1, \text { jika } d_{k l} \geq \underline{d} \\
0, \text { jika } d_{k l}<\underline{d}
\end{array}\right.
$$

Step 7. Formation of Total Dominance matric $(E)$

Aggregate dominance matrix $(E)$, merupakan perkalian antara elemen matrik $F$ dengan elemen matrik $G$ yang bersesuaian, diformulasikan: $e_{k l}=f_{k l} x g_{k l}$, nilai yang diperoleh menggambarkan tingkat preferensi alternatif satu terhadap alternatif yang dibandingkan.

Step 8. Defining the Importance Order of The Decision Points

Matriks $E$ memberikan urutan pilihan dari setiap alternatif, yaitu bila $e_{k l}=1$ maka alternatif $A_{k}$ adalah alternatif yang lebih baik dari $A_{l}$. Baris dalam matriks $E$ yg memiliki jumlah $e_{k l}$ 
$=1$ paling sedikit dapat dieliminasi. Alternatif terbaik adalah alternatif yang mendominasi alternatif lainnya.

\section{IMPLEMENTASI METODE ELECTRE}

Perancangan bentuk roda gigi dipengaruhi oleh beberapa faktor yang menjadi penentu dalam pemilihan bentuk rancangan yang lebih baik. Faktor-faktor tersebut diantaranya ukuran geometri, tegangan lengkung, tegangan kontak, standar kepresisian dan halus tidaknya roda gigi dalam mentranmisikan gaya dan momen. Beberapa material yang digunakan dalam pembuatan roda gigi diantaranya baja dengan pengerasan nyala api yang mempunyai tegangan kontak 170 ksi dan tegangan lengkung 45 ksi. Besi cor kelabu mempunyai tegangan kontak 65 ksi dan tegangan lengkung $8,5 \mathrm{ksi}$, perunggu cor pasir dengan tegangan kontak $30 \mathrm{ksi}$ dan tegangan lengkung 5,7 ksi. (Mott, 2004). Karakteristik kualitas material berkaitan dengan standar kepresisian roda gigi berdasar standar kualitas AGMA 2015 dan ISO 1328. Kedua standar ini memberikan tingkatan angka kualitas dari 1 s/d 15 yang menunjukkan semakin kecil angka semakin tinggi tingkat kepresisiannya. Ukuran geometri berkaitan dengan besar kecillnya bentuk susunan rancangan roda gigi dalam kontruksi mesin. Hal ini berkaitan dengan kebutuhan rancangan elemen mesin serta biaya yang harus dikeluarkan. Pendekatan metode ELECTRE yang bertujuan mengusulkan model pemilihan bentuk rancangan roda gigi yang terbaik melalui pemilihan alternatif berdasar kriteria yang ada. Model ini digunakan untuk membandingkan 4 pilihan berdasarkan beberapa kriteria yang berpengaruh dalam perancangan roda gigi yaitu aspek material berkaitan dengan tegangan kontak dan tegangan lengkung, standar kepresisian, ukuran geometri, dan kehalusan kondisi petransmisian.

Pada kasus ini menggunakan metode ELECTRE untuk melakukan pemilihan rancangan roda gigi dengan cara melakukan perangkingan beberapa alternatif yang ditetapkan. Berikut ini penilaian bobot yang diberikan kepada kriteria yang berpengaruh dalam rancangan roda gigi.

Tabel 1. Bobot Kriteria Material Rancangan

\begin{tabular}{|l|l|c|c|}
\hline \multicolumn{2}{|c|}{ Kriteria } & \multicolumn{2}{c|}{ Bobot Kriteria } \\
\hline$C 1$ & Tegangan Kontak (ksi) & $W 1$ & 0,3 \\
\hline$C 2$ & Kehalusan Petransmisian & $W 2$ & 0,1 \\
\hline$C 3$ & Tegangan lengkung (ksi) & $W 3$ & 0,3 \\
\hline$C 4$ & Standar kepresisian (ISO 1328) & $W 4$ & 0,2 \\
\hline$C 5$ & Ukuran Geometri & $W 5$ & 0,1 \\
\hline
\end{tabular}

Penilaian kriteria yang menggambarkan karakteristik material yang mempengaruhi perancangan roda gigi ditetapkan melalui studi literatur dan diskusi dengan para ahli engineering untuk menentapkan pilihan kriteria yang ada. Selain itu ditetapkan pula empat pilihan alternatif yang menjadi dasar bagi decision maker dalam mengambil suatu keputusan berdasar pertimbangan kriteria yang ada. Hubungan antara beberapa kriteria dan pilhan alternatif yang ditetapkan diperlihatkan dalam tabel berikut ini.

Tabel 2. Pilihan Alternatif dan Kriteria dalam Matrik Keputusan.

\begin{tabular}{|c|c|c|c|c|c|}
\hline & Kriteria 1 & Kriteria 2 & Kriteria 3 & Kriteria 4 & Kriteria 5 \\
\hline$A 1$ & 150 & Halus & 40 & 3 & kecil \\
\hline$A 2$ & 180 & Kasar & 60 & 6 & besar \\
\hline$A 3$ & 77 & Sedang & 40 & 4 & sedang \\
\hline$A 4$ & 65 & Halus & 30 & 10 & besar \\
\hline
\end{tabular}

Berdasarkan tabel diatas dibuat kedalam bentuk matrik dengan mengkonversi angka penilaian awal menjadi bentuk matrik keputusan (decision matrix) dengan angka dapat diperbandingkan (comparable). Matrik keputusan merupakan langkah awal dalam perhitungan metode ELECTRE yang ditunjukkan sebagai berikut : 


$$
D=\left[\begin{array}{cccc}
X_{11} & X_{12} & \cdots & X_{1 n} \\
X_{21} & X_{22} & \cdots & X_{2 n} \\
\vdots & \vdots & & \vdots \\
X_{m 1} & X_{m 2} & \cdots & X_{m n}
\end{array}\right]
$$

Decision matrix $D$ mengacu terhadap m alternatif yang akan dievaluasi berdasarkan $\mathrm{n}$ kriteria yang ada hasilnya sebagai berikut:

$D=\left[\begin{array}{ccccc}150 & 4 & 40 & 3 & 2 \\ 180 & 2 & 60 & 6 & 4 \\ 77 & 3 & 40 & 4 & 3 \\ 65 & 4 & 30 & 10 & 4\end{array}\right]$

Matrik keputusan yang telah disusun kemudian dilakukan proses normalisasi untuk mengubah nilai atribut menjadi nilai yang comparable. Proses normalisasi menggunakan rumus $r_{i j}$ untuk memperoleh matrik hasil normalisasi $(R)$, dengan tahapan sebagai berikut :

$$
r_{i j}=\frac{x_{i j}}{\sqrt{\sum_{i=1}^{m} x_{i j}^{2}}} \text { untuk } i=1,2,3, \ldots, \text { m dan } j=1,2,3, \ldots, n \text {. }
$$

Tabel 3. Langkah - langkah Normalisasi

\begin{tabular}{|c|c|c|c|c|c|}
\hline & $\mathrm{C} 1$ & $\mathrm{C} 2$ & $\mathrm{C} 3$ & $\mathrm{C} 4$ & $\mathrm{C} 5$ \\
\hline & 150 & 4 & 40 & 3 & 2 \\
\hline & 180 & 2 & 60 & 6 & 4 \\
\hline & 77 & 3 & 40 & 4 & 3 \\
\hline & 65 & 4 & 30 & 10 & 4 \\
\hline$\Sigma \mathrm{X}_{\mathrm{ij}}{ }^{2}$ & 65054 & 45 & 7700 & 161 & 45 \\
\hline$\sqrt{\Sigma \mathrm{X}_{\mathrm{ij}}}{ }^{2}$ & 255 & 6,71 & 87,75 & 12,67 & 6,71 \\
\hline
\end{tabular}

Tabel 4. Matrik Hasil Normalisasi $(R)$

\begin{tabular}{|c|c|c|c|c|}
\hline $\mathrm{C} 1$ & $\mathrm{C} 2$ & $\mathrm{C} 3$ & $\mathrm{C} 4$ & $\mathrm{C} 5$ \\
\hline 0,588 & 0,596 & 0,456 & 0,237 & 0,298 \\
\hline 0,706 & 0,298 & 0,684 & 0,474 & 0,596 \\
\hline 0,302 & 0,447 & 0,456 & 0,316 & 0,447 \\
\hline 0,255 & 0,596 & 0,342 & 0,789 & 0,596 \\
\hline
\end{tabular}

Selanjutnya matrik normalisasi dikalikan dengan bobot yang telah ditetapkan sebelumnya dengan cara matrik $R$ dikalikan dg bobot $\left(w_{j}\right)$ shg diperoleh matrik terbobot (weighted normalized matrix) , $V=R W$.

$$
V=\left[\begin{array}{cccc}
w_{1} r_{11} & w_{2} r_{12} & \cdots & w_{n} r_{1 n} \\
w_{1} r_{21} & w_{2} r_{22} & \cdots & w_{n} r_{2 n} \\
\vdots & \vdots & & \vdots \\
w_{1} r_{m 1} & w_{2} r_{m 2} & \cdots & w_{n} r_{m n}
\end{array}\right]
$$


Tabel 5. Matrik Normalisasi Terbobot

\begin{tabular}{|c|c|c|c|c|}
\hline C1 & C2 & C3 & C4 & C5 \\
\hline 0,176 & 0,060 & 0,137 & 0,047 & 0,030 \\
\hline 0,212 & 0,030 & 0,205 & 0,095 & 0,060 \\
\hline 0,091 & 0,045 & 0,137 & 0,063 & 0,045 \\
\hline 0,077 & 0,060 & 0,103 & 0,158 & 0,060 \\
\hline
\end{tabular}

Selanjutnya dilakukan penentuan nilai Determination of Concordance $\left(C_{k l}\right)$ dan Discordance $\left(D_{k l}\right)$ berdasarkan matrik terbobot yang telah diperoleh dengan ketentuan sebuah kriteria dalam suatu alternatif termasuk concordance jika $C_{k l}=\left\{j, v_{k j} \geq v_{l j}\right\}$, untuk $j=1,2,3, \ldots, n$. Dan termasuk discordance jika $D_{k l}=\left\{j, v_{k j}<v_{l j}\right.$, untuk $j=1,2,3, \ldots n$.

Untuk perbandingan $C_{12}=\left\{j, v_{1 j} \geq v_{2 j}\right\}$, diperoleh pada kriteria 2 nilai $0,06>0,03$ sehingga nilai concordance $C_{12}=0,1$.

Tabel 6. Perbandingan $C_{12}$ dalam Penentuan Nilai Concordance

\begin{tabular}{|c|c|c|c|c|c|}
\hline$C_{12}$ & $C 1$ & $C 2$ & $C 3$ & $C 4$ & $C 5$ \\
\hline 1 & 0,176 & 0,060 & 0,137 & 0,047 & 0,030 \\
\hline 2 & 0,212 & 0,030 & 0,205 & 0,095 & 0,060 \\
\hline
\end{tabular}

Hasil perhitungan nilai himpunan concordance ditampilkan dalam tabel berikut ini.

Tabel 7. Nilai Concordance $(C)$

\begin{tabular}{|c|c|c|c|}
\hline Concordance $(\mathrm{C})$ & Himpunan & Nilai bobot & Jumlah bobot \\
\hline$C 12$ & 2 & 0,1 & 0,1 \\
\hline$C 13$ & $1,2,3$ & 0,$3 ; 0,1 ; 0,3$ & 0,7 \\
\hline$C 14$ & $1,2,3$ & 0,$3 ; 0,1 ; 0,3$ & 0,7 \\
\hline$C 21$ & $1,3,4,5$ & 0,$3 ; 0,3 ; 0,2 ; 0,1$ & 0,9 \\
\hline$C 23$ & $1,3,4,5$ & 0,$3 ; 0,3 ; 0,2 ; 0,1$ & 0,9 \\
\hline$C 24$ & $1,3,5$ & 0,$3 ; 0,3 ; 0,1$ & 0,7 \\
\hline$C 31$ & $3,4,5$ & 0,$3 ; 0,2 ; 0,1$ & 0,6 \\
\hline$C 32$ & 2 & 0,1 & 0,1 \\
\hline$C 34$ & 1,3 & 0,$3 ; 0,3$ & 0,6 \\
\hline$C 41$ & $2,4,5$ & 0,$1 ; 0,2 ; 0,1$ & 0,4 \\
\hline$C 42$ & $2,4,5$ & 0,$1 ; 0,2 ; 0,1$ & 0,4 \\
\hline$C 43$ & $2,4,5$ & 0,$1 ; 0,2 ; 0,1$ & 0,4 \\
\hline
\end{tabular}

Komplementer dari himpunan bagian concordance adalah himpunan discordance, nilai discondance diperoleh jika nilai $D_{k l}=\left\{j\right.$, $\left.v_{k j}<v_{l j}\right\}$, untuk $j=1,2,3, \ldots n$. Hasil dari perhitungan diperoleh himpunan discordance ditunjukkan dalam tabel dibawah ini.

Tabel 8. Himpunan Discordance

\begin{tabular}{|c|c|c|c|}
\hline $\begin{array}{c}\text { Discordance } \\
(D)\end{array}$ & Himpunan & Discordance $(D)$ & Himpunan \\
\hline$D 12$ & $1,3,4,5$ & $D 31$ & 1,2 \\
\hline$D 13$ & 4,5 & $D 32$ & $1,3,4,5$ \\
\hline$D 14$ & 4,5 & $D 34$ & $2,4,5$ \\
\hline$D 21$ & 2 & $D 41$ & 1,3 \\
\hline$D 23$ & 2 & $D 42$ & 1,3 \\
\hline$D 24$ & 2,4 & $D 43$ & 1,3 \\
\hline
\end{tabular}


Tahap selanjutnya dilakukan penentuan nilai matrik concordance dan matrik discordance (Concordance and Discordance Matrices). Perhitngan matrik discordance dilakukan dengan formulasi berikut:

$$
c_{k l}=\sum_{j \in C_{k l}} w_{j}
$$

Dari perhitungan dengan rumus concordance diatas diperoleh hasil seperti tabel berikut ini:

Tabel 9. Hasil perhitungan himpunan concordance (C).

\begin{tabular}{|c|c|c|c|}
\hline $\begin{array}{c}\text { Concordance } \\
(C)\end{array}$ & Jumlah bobot & $\begin{array}{c}\text { Concordance } \\
(C)\end{array}$ & Jumlah bobot \\
\hline$C 12$ & 0,1 & $C 31$ & 0,6 \\
\hline$C 13$ & 0,7 & $C 32$ & 0,1 \\
\hline$C 14$ & 0,7 & $C 34$ & 0,6 \\
\hline$C 21$ & 0,9 & $C 41$ & 0,4 \\
\hline$C 23$ & 0,9 & $C 42$ & 0,4 \\
\hline$C 24$ & 0,7 & $C 43$ & 0,4 \\
\hline
\end{tabular}

Dari nilai himpunan concordance diatas dilakukan tabulasi sesuai urutan baris dan kolom sehingga diperoleh matrik concordance sebagai berikut:

$$
C=\left[\begin{array}{cccc}
- & 0,1 & 0,7 & 0,7 \\
0,9 & - & 0,9 & 0,7 \\
0,6 & 0,1 & - & 0,6 \\
0,4 & 0,4 & 0,4 & -
\end{array}\right]
$$

Menghitung matriks discordance:

$$
\begin{aligned}
d_{k l} & =\frac{\max \left\{\left|v_{k j}-v_{l j}\right|\right\}_{j \in D_{k l}}}{\max \left\{\left|v_{k j}-v_{l j}\right|\right\}_{\forall j}} \\
d_{12}= & \frac{\max \left(\left|V_{1 j}-V_{2 j}\right|\right), j \in D_{12}}{\max \left(\left|V_{1 j}-V_{2 j}\right|\right) \forall_{j}} \\
d_{12}= & \frac{(|0,176-0,212| ;|0,137-0,205| ;|0,047-0,095| ;|0,030-0,060|)}{(|0,176-0,212| ;|0,060-0,030| ;|0,137-0,205| ;|0,047-0,095| ;|0,030-0,060|)} \\
d_{12}= & \frac{(0,036 ; 0,068 ; 0,048 ; 0,03)}{(0,036 ; 0,03 ; 0,068 ; 0,048 ; 0,03)}=\frac{0,068}{0,068}=1 \\
d_{13}= & \frac{(|0,047-0,063| ;|0,030-0,045|)}{(|0,176-0,091| ;|0,060-0,045| ;|0,137-0,137| ;|0,047-0,063| ;|0,030-0,045|)} \\
d_{13}= & \frac{(0,016 ; 0,015)}{(0,085 ; 0,015 ; 0 ; 0,026 ; 0,015)}=\frac{0,016}{0,085}=0,188
\end{aligned}
$$

Tabel 10. Penentuan Matrik Discordance

\begin{tabular}{|c|c|c|c|}
\hline $\begin{array}{c}\text { Matrik } \\
\text { Discordance }\left(\mathrm{d}_{\mathrm{kl}}\right)\end{array}$ & Nilai & $\begin{array}{c}\text { Matrik } \\
\text { Discordance }\left(\mathrm{d}_{\mathrm{kl}}\right)\end{array}$ & Nilai \\
\hline$d 12$ & 1,0 & $d 31$ & 1,0 \\
\hline$d 13$ & 0,188 & $d 32$ & 1,0 \\
\hline$d 14$ & 1,0 & $d 34$ & 1,0 \\
\hline$d 21$ & 0,441 & $d 41$ & 0,892 \\
\hline$d 23$ & 0,124 & $d 42$ & 1,0 \\
\hline$d 24$ & 0,467 & $d 43$ & 0,358 \\
\hline
\end{tabular}


Dari nilai himpunan discordance diatas dilakukan tabulasi sesuai urutan baris dan kolom sehingga diperoleh matrik discordance sebagai berikut:

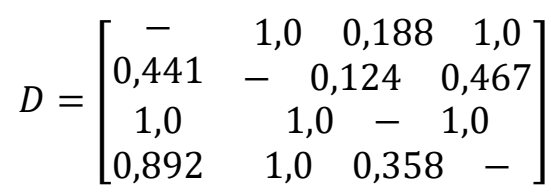

Tahap berikutnya menentukan matrik dominan concordance dan matrik dominan dicordance. Matriks $F$, matriks dominan concordance diperoleh dg nilai threshold,

$C_{k l} \geq \underline{c}$, dengan formulasi nilai threshold $(\underline{c})$ :

$\underline{c}=\frac{1}{m(m-1)} \sum_{k=1}^{m} \sum_{l=1}^{m} c_{k l}$

Shg elemen matriks $F$ ditentukan sbb:

$$
f_{k l}=\left\{\begin{array}{l}
1, \text { jika } c_{k l} \geq \underline{c} \\
0, \text { jika } c_{k l}<\underline{c}
\end{array}\right.
$$

$\underline{c}=\frac{1}{4(4-1)}(0,1+0,7+0,7+0,9+0,9+0,7+0,6+0,1+0,6+0,4+0,4+0,4)$

$\underline{c}=\frac{1}{12}(6,5)=0,542$

Dengan membandingkan nilai matrik concordance $(C)$ terhadap nilai threshold $(\underline{c})$ diperoleh matrik dominan concordance $(F)$ sebagai berikut:

$F=\left[\begin{array}{cccc}- & 0 & 1 & 1 \\ 1 & - & 1 & 1 \\ 1 & 1 & - & 1 \\ 0 & 0 & 0 & -\end{array}\right]$

Matrik $G$ sebagai matriks dominan discordance dapat dibangun dg bantuan nilai threshold $\underline{d}$ : $\underline{d}=\frac{1}{m(m-1)} \sum_{k=1}^{m} \sum_{l=1}^{m} d_{k l}$

Elemen matriks $\mathrm{G}$ ditentukan sbb:

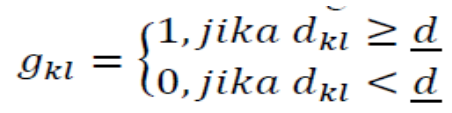$$
\underline{d}=\frac{1}{4(4-1)}(1+0,188+1+0,441+0,124+0,467+1+1+1+0,892+1+0,358)
$$

$\underline{d}=\frac{1}{12}(8,47)$

Dengan membandingkan nilai matrik discordance $(D)$ terhadap nilai threshold $(\underline{d})$ diperoleh matrik dominan concordance $(G)$ sebagai berikut:

$G=\left[\begin{array}{cccc}- & 1 & 0 & 1 \\ 0 & - & 0 & 0 \\ 1 & 1 & - & 1 \\ 1 & 1 & 0 & -\end{array}\right]$

Tahap selanjutnya menentukan Total Dominance matric $(E)$, aggregate dominance matrik merupakan perkalian antara elemen matrik dominance concordance $(F)$ dg elemen matrik 
dominance discordance $(\mathrm{G})$ yang bersesuaian, diformulasikan: $e_{k l}=f_{k l} \times g_{k l}$. Berdasarkan perhitungan diperoleh agregat dominan matrik sebagaimana ditunjukkan dalam tabel berikut:

Tabel 11. Agregat Dominan Matrix $\left(e_{k l}\right)$

\begin{tabular}{|c|c|c|c|}
\hline & $\mathrm{F}$ & $\mathrm{G}$ & Hasil \\
\hline$e_{12}$ & 0 & 1 & 0 \\
\hline$e_{13}$ & 1 & 0 & 0 \\
\hline$e_{14}$ & 1 & 1 & 1 \\
\hline$e_{21}$ & 1 & 0 & 0 \\
\hline$e_{23}$ & 1 & 0 & 0 \\
\hline$e_{24}$ & 1 & 0 & 0 \\
\hline$e_{31}$ & 1 & 1 & 1 \\
\hline$e_{32}$ & 0 & 1 & 0 \\
\hline$e_{34}$ & 1 & 1 & 1 \\
\hline$e_{41}$ & 0 & 1 & 0 \\
\hline$e_{42}$ & 0 & 1 & 0 \\
\hline$e_{43}$ & 0 & 0 & 0 \\
\hline
\end{tabular}

Berdasarkan tabel diatas diperoleh nilai untuk $e_{14}, e_{31}$ dan $e_{41}$ bernilai 1 sedangkan yang lainnya bernilai 0 , artinya untuk nilai 1 dipilih karena menggambarkan tingkat preferensi suatu pilihan yang lebih disukai dari pilihan yang lainnya. Misalnya untuk nilai $e_{14}$ menggambarkan alternatif 1 lebih disukai dari alternatif 4 .

$E=\left[\begin{array}{cccc}- & 0 & 0 & 1 \\ 0 & - & 0 & 0 \\ 1 & 0 & - & 1 \\ 0 & 0 & 0 & -\end{array}\right]$

Tabel 12. Perangkingan Urutan Pilihan.

\begin{tabular}{|c|c|c|c|c|c|c|}
\hline Pilihan & \multicolumn{4}{|c|}{ Total Dominance matrix } & Total nilai & Rangking \\
\hline$A 1$ & - & 0 & 0 & 1 & 1 & 2 \\
\hline$A 2$ & 0 & - & 0 & 0 & 0 & 3 \\
\hline$A 3$ & 1 & 0 & - & 1 & 2 & 1 \\
\hline A4 & 0 & 0 & 0 & - & 0 & 3 \\
\hline
\end{tabular}

Berdasarkan tabel diatas pilihan 3 lebih unggul dari pilihan 1, 2 dan 4, sedangkan pilihan 1 lebih unggul dari pilihan 2 dan 4. Dari hasil nilai tersebut menggambarkan alternatif 3 lebih dipilih dengan nilai total dominance matrik 2, sedangkan alternatif 1 dengan nilai total 2, sedangkan pilihan 2 dan 4 bernilai sama yaitu 0 .

\section{ANALISIS HASIL DAN PEMBAHASAN}

Kriteria yang dipilih dari aspek karakteristik material diantaranya, besarnya tegangan kontak roda gigi dengan satuan ksi, tegangan lengkung roda gigi satuan ksi, standar kepresisian mengacu pada standar internasionl ISO 1328 dengan besaran nilai antara 0 sampai dengan 15 dimana semakin kecil angka menunjukkan kondisi roda gigi semakin presisi. Selain itu ditetapkan karakteristik material berkaitan dengan tingkat kehalusan dalam pentransmisian, dan ukuran geometri roda gigi. Kehalusan petransmisian dipengaruhi jenis rancangan roda gigi, roda gigi miring mempunyai tingkat kehalusan lebih dibanding jenis yang lain. Sedangkan ukuran geometri berkaitan dengan susunan roda gigi dalam kontruksi mesin. Kebutuhan ukuran geometri akan mempengaruhi besar kecilnya konstruksi mesin yang akan dibuat akan berpengaruh terhadap biaya produksi yang harus dikeluarkan. Pemilihan rancangan roda gigi berdasar karakteristik material terkadang menjadi suatu dillema bagi perancangan material, beberapa karakteristik 
material kadang-kadang punya pengaruh yang sama berkaitan dengan kualitas material yang akan dipilih. Kondisi ini menyebabkan permasalahan yang konfliktual dan membutuhkan pertimbangan yang logis, ekonomis dan proporsional dalam menentukan pilihan rancangan. Permasalahan ini dapat dipecahkan dengan metode multicriteria decision making untuk memilih beberapa alternatif rancangan dengan mempertimbangkan performansi karakteristik material.

Salah satu metoda MCDM yang digunakan dalam studi ini adalah metode ELECTRE dengan kelebihan memiliki kemampuan untuk mengolah kriteria kuantitatif dan kualitatif diskrit secara alami dan memberikan pengurutan sampel secara penuh, mengakomodasi ketidakakuratan dan ketidaktentuan dalam proses pengambilan keputusan menggunakan nilai concordance, discordance dan threshold. Dalam melakukan perhitungan dengan metode ELECTRE menggunakan urutan langkah sebagai berikut : menetapkan pilihan alternatif dan pertimbangan kriteria dalam suatu matrik keputusan (decision matriks), mengubah bilangan matrik menjadi bilangan yang comparable dengan langkah normalisasi matrik. Selanjutnya mengalikan matrik yang ternormalisasi dengan matrik bobot untuk mendapatkan matrik keputusan yang terbobot yang menjadi acuan untuk menentukan nilai himpunan concordance dan discordance. Nilai himpunan ini menjadi dasar dalam penentuan matrik concordance dan discordance. Langkah berikutnya menentukan concordance supremacy matrix dan discordance supremacy matrix dengan membandingkan nilai matrik concordance dan discordance dengan nilai threshold yang telah ditetapkam apabila lebih besar dari nilai threshold akan bernilai satu, sebaliknya apabila kurang dari nilai threshold akan bernilai nol. Untuk memperoleh urutan perangkingan dilakukan dengan menentukan nilai agregat dominan matrix $\left(\mathrm{e}_{\mathrm{kl}}\right)$ melalui perkalian matrik supremacy concordance $(\mathrm{F})$ dangan matrik supremacy discordance $(\mathrm{G})$. Berdasarkan perhitungan agregat dominan matrix diperoleh alternatif 3 mempunyai nilai 2, disusul alternatif 1 dengan nilai 1 dan alternatif 2 dan alternatif 4 dengan nilai 0 . Berdasarkan nilai tersebut diatas (tabel 12) dapat ditentukan urut-urutan pilihan A3>A1>A4>A2. Alternatif A2 dan A4 bernilai sama (nilai 0) tetapi dalam perhitungan agregat dominance matrix, nilai $\mathrm{e}_{\mathrm{kl}}$ untuk pilihan $\mathrm{A} 4$ bernilai satu sedangkan nilai $e_{\mathrm{k} l}$ untuk alternatif A2 bernilai 0 sehingga A4 lebih dipilih dari A2 (lihat tabel 11). Berdasarkan urutan yang diperoleh (tabel 12) decision maker lebih mempertimbangkan pilihan rancangan roda gigi dengan karakteristik material dengan tegangan kontak $77 \mathrm{ksi}$, tegangan lengkung $40 \mathrm{ksi}$, standar kepresisian dengan besaran nilai 4, angka ini menunjukkan angka kepresisian yang tinggi, ukuran geometri yang sedang, menunjukkan susunan dalam struktur mesin tidak kecil dan tidak besar dan tingkat kehalusan dalam petransmisian dalam kondisi sedang, menunjukan jenis roda gigi yang digunakan dapat berbentuk lurus atau miring.

\section{KESIMPULAN}

Dengan pendekatan multikriteria diberikan hubungan beberapa alternatif pilihan rancangan roda gigi dengan mempertimbangkan kriteria yang ditetapkan. Analisa multikriteria memberikan hasil suatu pilihan rancangan roda gigi berdasarkan pilihan kriteria yang ada. Metode yang digunakan dalam analisa dengan model ELECTRE yaitu model multikriteria dengan pendekatan outrangking untuk membantu decision maker memilih alternatif terbaik dari sekumpulan alternatif yang ada. Pendekatan Metode ELECTRE meliputi pembentukan matrik decision, normalisasi matrik decision, pembobotan matrik, penentuan himpunan cocordance dan discordance, penentuan matriks concordance dan matrik discordance, penentuan concordance and discordance supremacy matrik, penentuan total dominasi matrik dan penentuan prioritas pilihan alternatif.

Hasil dari analisa dengan model ELECTRE diperoleh nilai agregat dominan matrik untuk alternatif 3 mempunyai nilai 2, alternatif 1 bernilai 1 dan alternatif 2 dan 4 bernilai sama yaitu 0 . Berdasarkan nilai yang diperoleh menghasilkan urut-urutan pilihan sebagai berikut alternatif 3 paling disukai dari alternatif 1 , alternatif 4 , dan alternatif 2 , alternatif 2 paling tidak disukai sehingga urut-urutannya $\mathrm{A} 3>\mathrm{A} 1>\mathrm{A} 4>\mathrm{A} 2$. 


\section{DAFTAR PUSTAKA}

Amania A, Spitas C, Spitas V, 2017, Generalised Non-Dimensional Multi-Parametric Involute Spur Gear Design Model Considering Manufacturability and Geometrical Compatibility, Elsevier, Journal of Mechanism and Machine Theory 109 (2017) 250-277.

Corrente S, Greco S, Slowinski R, 2013, Multiple Criteria Hierarchy Process with ELECTRE and PROMETHEE, Elsevier, Journal of Omega (2013) 820-846.

Ferdinand P. Beer \& E.Russell Johnston, 1991, Mekanika untuk Insinyur : Statika, Terjemahan, Penerbit Erlangga, Jakarta.

George Sebastian Naghiu, Ioan Giurca, Ioan Aschilean, Gheorghe Badea, 2016, Multicriterial Analysis on Selecting Solar Radiation Concentration Ration for Photovoltaic Panels Using ELECTRE-Boldur Method, Elsevier, Journal of Procedia Technology 22(2016) 773-780.

H.Tezcan Uysal, Kemal Yavuz, 2014, Selection of Logistics Centre Location via ELECTRE Method : A Case Study in Turkey, International Journal of Business and Social Science, Vol. 5, No. 9, pp. 276-289.

Ishizaka A, Nemery P, 2013, Multi-Criteria Decision Analysis Methods and Software, First Edition first, John Wiley \& Sons, Ltd, United Kingdom.

J.M. Sanchez-Lozano, M.S. Garcia-Cascales, M.T. Lamata, 2016, Comparative TOPSISELECTRE TRI Methods for Optimal Sites for Photovoltaic Solar Farms. Case Study in Spain, Elsevier, Journal of Cleaner Production 127(2016) 387-398

John Buchanan and Phil Sheppard, Ranking Projects Using the ELECTRE Method, Department of Management Systems, University of Waikato Hamilton, New Zealand.

Kadzinski M, Ciomek K, 2016, Integrated framework for preference modeling and robustness analysis for outranking-based multiple criteria sorting with ELECTRE and PROMETHEE, Elsevier, Journal of Information Sciences 352-353 (2016) 167-187.

Karim R and Karmaker C.L, 2016, Machine Selection by AHP and TOPSIS Method, American Journal of Industrial Engineering, Vol.4, No.1, pp 7-13.

Korta J, Mundo D, 2017, Multi-Objective Micro-Geometry Optimization of Gear Tooth Supported by Response Surface Methodology, Elsevier, Journal of Mechanism and Machine Theory 109 (2017)278-295.

Kosky P, Wise G, Balmer R, Keat W, 2010, Exploring Engineering : An Introduction to Engineering \& Design, Academic Press, Elsevier Inc., USA.

Kusdiantoro, 2012, Analisis Usability Website Akademik Perguruan Tinggi di Indonesia Menggunakan Metode Promethee, Vikor, dan Electree, Skripsi, Jurusan Pendidikan Teknik Elektronika, Fakultas Teknik, Universitas Negeri Yogyakarta.

Olanrewaju Joseph Soniran Shofade, 2011, Considering Hierarchical Structure of Criteria in ELECTRE Decision Aiding Methods, Master Thesis, Department of Computer Engineering and Mathematics, University of Rovira and Virgili, Polandia.

Robert L. Mott, 2004, Machine Elements in Mechanical Design, Fourth Edition, Prentice Hall, USA.

Shigley. Joseph.E. \& Mitchell. Larry D.,1984, Perencanaan Teknik Mesin, Terjemahan, Edisi 4, Penerbit Erlangga, Jakarta. 